\title{
Percutaneous transluminal angioplasty for renovascular hypertension
}

\author{
M AWAZU, M SHIMIZU, H HOJO, M OSANO, AND E KOHDA \\ Department of Paediatrics and Diagnostic Radiology, School of Medicine, Keio University, Tokyo, Japan
}

SUMMARY Five children with renovascular hypertension were treated with percutaneous transluminal angioplasty, and followed for 12 to 32 months. Blood pressure fell to normal in four patients and improved in one. Angiographic and endocrinological improvements were associated with a fall in blood pressure and no complications were observed. Angioplasty is considered a safe, effective treatment for children with renovascular hypertension.

Renovascular hypertension has traditionally been treated with renovascular surgery or nephrectomy of the affected side. Recently, however, with the development of double lumen catheter with an expansible balloon, percutaneous transluminal angioplasty has emerged as a less invasive treatment. ${ }^{1-3}$ The pressure of the inflated balloon fractures the stenotic lesion, stretching the vessel wall, and expanding the lumen. Since few reports of its application to children have been published, ${ }^{4-6}$ we report our experience with angioplasty in five children with renovascular hypertension.

\section{Patients and methods}

Peripheral blood was withdrawn for measurements of plasma renin activity and aldosterone early in the morning, after at least $\mathbf{3 0}$ minutes of supine rest. Patients had been put on a diet with a sodium content of $9 \mathrm{~g} /$ day for at least three days before blood sampling. Drugs had been stopped two weeks before blood sampling and the 1-sarcosine, 8isoleucine angiotensin II infusion test. Plasma renin activity and aldosterone were measured by radioimmunoassay.

Patients were sedated before angioplasty, which was done under local anaesthesia. Only patient 4 received general anaesthesia because of his age. Angioplasty procedure was as follows. When a Grüntzig catheter was properly positioned, the balloon was inflated for 10 seconds with a filling pressure of $9 \mathrm{~atm}$, and this was repeated three times. To avoid postoperative thrombosis, aspirin (20 $\mathrm{mg} / \mathrm{kg}$ per day) was given for two weeks.

\section{Case reports}

Patients were selected according to the presence of stenotic lesion on angiography. Their clinical data are presented in Table 1 .

\section{Patient 1}

A 9 year old girl was admitted to hospital because of vomiting and headache; hypertension was noticed. Plasma renin activity and aldosterone values were high, and she was diagnosed by angiography as having stenoses of both renal arteries. After performing angioplasty, ganglion blocker was also administered, but no hypotensive effect was achieved. She was therefore transferred to our hospital. Angiography confirmed stenosis of the left main and right distal renal arteries. Angioplasty was performed on the left side, after which her blood pressure fell and has subsequently remained well controlled with captopril and furosemide.

Table 1 Clinical data for five patients with renovascular hypertension

\begin{tabular}{|c|c|c|c|c|c|}
\hline $\begin{array}{l}\text { Patient } \\
\text { no }\end{array}$ & $\begin{array}{l}\text { Age } \\
\text { (yrs) }\end{array}$ & Sex & $\begin{array}{l}\text { Blood pressure (mm } \\
\text { Before angioplasty } \\
\text { (highest) }\end{array}$ & $\begin{array}{l}\mathrm{Hg}) \\
\text { After angioplasty* }\end{array}$ & $\begin{array}{l}\text { Duration o } \\
\text { follow up } \\
\text { (mths) }\end{array}$ \\
\hline 1 & 10 & $\mathbf{F}$ & $242 / 168$ & $124 / 88$ & 32 \\
\hline 2 & 5 & $\mathbf{F}$ & $240 / 170$ & $110 / 70$ & 12 \\
\hline \multirow[t]{2}{*}{3} & 16 & $\mathbf{M}$ & $220 / 150$ & $160 / 120$ (first) & 27 \\
\hline & & & $174 / 140$ & $140 / 80$ (second) & \\
\hline 4 & 1 & $\mathbf{M}$ & $140 / 80$ & $110 / 50$ & 12 \\
\hline 5 & 12 & $\mathbf{F}$ & $170 / 100$ & $120 / 80$ & 12 \\
\hline \multicolumn{3}{|c|}{ Mean (SEM) } & $164(33) / 135(15)$ & $127(8) / 81(9)$ & $19(4)$ \\
\hline
\end{tabular}

*Values measured one month after angioplasty. 


\section{Patient 2}

A 5 year old girl attended hospital because of impairment of visual acuity in the right eye. Hypertension and hypertensive retinopathy were found on examination. Angiography showed stenosis of the left renal artery and the patient was referred to our hospital for treatment. Her plasma renin activity was $9.5 \mathrm{ng} / \mathrm{ml}$ per hour and the aldosterone concentration was $0.36 \mathrm{pmol} / \mathrm{l}$. Stenosis of the left renal artery was confirmed by angiography. Angioplasty was performed, after which no medication has been needed and the patient's blood pressure has remained normal.

\section{Patient 3}

This 12 year old boy with café au lait spots was originally admitted to hospital at the age of 10 years because of diarrhoea and dehydration. Hypertension was noted, and he was diagnosed as having renovascular hypertension associated with neurofibromatosis. Hypertension was not well controlled with captopril, furosemide, and a beta blocker, and he was therefore transferred to our hospital. His plasma renin activity was $19.5 \mathrm{ng} / \mathrm{ml}$ per hour, and the aldosterone concentration was $2.3 \mathrm{nmol} / \mathrm{l}$. With the intravenous infusion of 1-sarcosine, 8 -isoleucine angiotensin II his blood pressure fell. Angiography confirmed stenosis of the right renal artery and angioplasty was performed. After angioplasty, hypertension was controlled with captopril, furosemide, and a beta blocker but because his blood pressure rose again, angioplasty was repeated seven months later. To date, hypertension has been controlled with the above drugs.

\section{Patient 4}

A 6 month old boy was noted on routine physical examination to have hepatomegaly; he was admitted to hospital and diagnosed as having hepatitis. During the course of his illness, hypertension was noted and he was transferred here. His plasma renin activity was $12.4 \mathrm{ng} / \mathrm{ml}$ per hour, and the aldosterone concentration was $0.93 \mathrm{nmol} / \mathrm{l}$. Blood pressure fell with intravenous infusion of l-sarcosine, 8-isoleucine angiotensin II. Angiography showed moderate stenosis of the right renal artery, and angioplasty was performed. After this his blood pressure fell and has subsequently remained normal.

\section{Patient 5}

This 11 year old girl attended hospital because of headache, and hypertension was found. The diagnosis of renovascular hypertension due to aortitis syndrome was made according to the angiographic findings and the blood test results. She was referred to our hospital after aortitis syndrome was controlled with aspirin. Her plasma renin activity was $10.8 \mathrm{ng} / \mathrm{ml}$ per hour and the aldosterone concentration was $0.87 \mathrm{nmol} / \mathrm{l}$. Her blood pressure fell after intravenous infusion of 1 -sarcosine, 8-isoleucine angiotensin II. Angiography showed stenosis of the right renal artery and angioplasty was performed. After angioplasty, her blood pressure became normal.

In patients 1, 2, and 4 no evidence of inflammation was found before the diagnosis and during the follow up period, therefore fibromuscular dysplasia was considered to be the underlying cause. In all patients, serum creatinine and blood urea nitrogen values were normal. Some underwent determination of creatinine clearance and this was also normal.

\section{Results}

Angiography. (Figs. 1 and 2). In patients 1, 2, and 4, widening of the stenosis was observed immediately after angioplasty. Angiography was repeated one year later in patients 1 and 2 and showed no stenosis. In patient 1 , angiography was repeated two
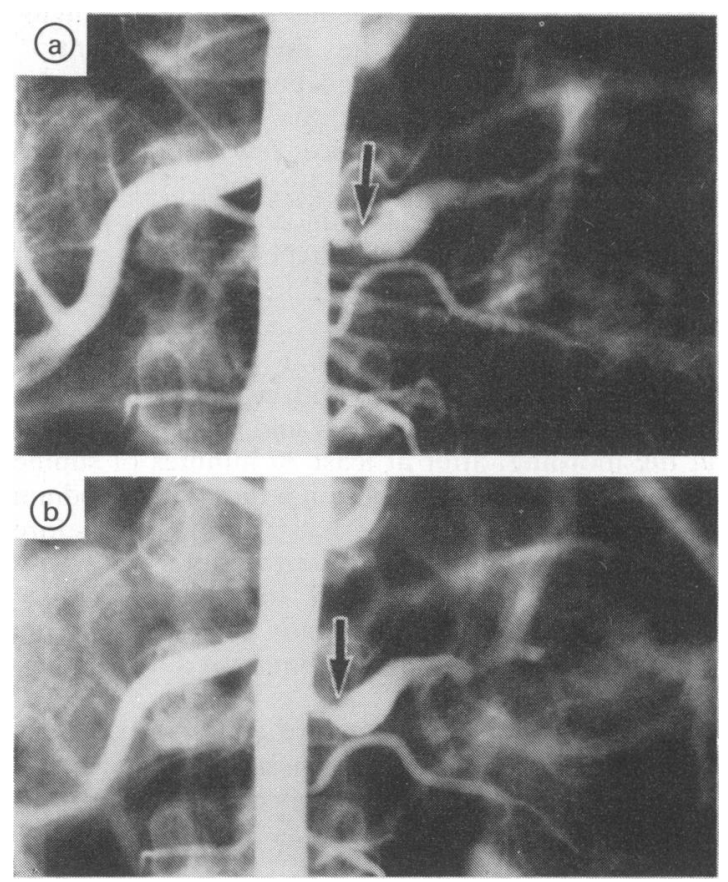

Fig. 1 Renal angiography of patient 2 with fibromuscular dysplasia showing (a) the left renal artery stenosis. Arteriogram (b), immediately after angioplasty, shows dilatation of the stenotic lesion. 

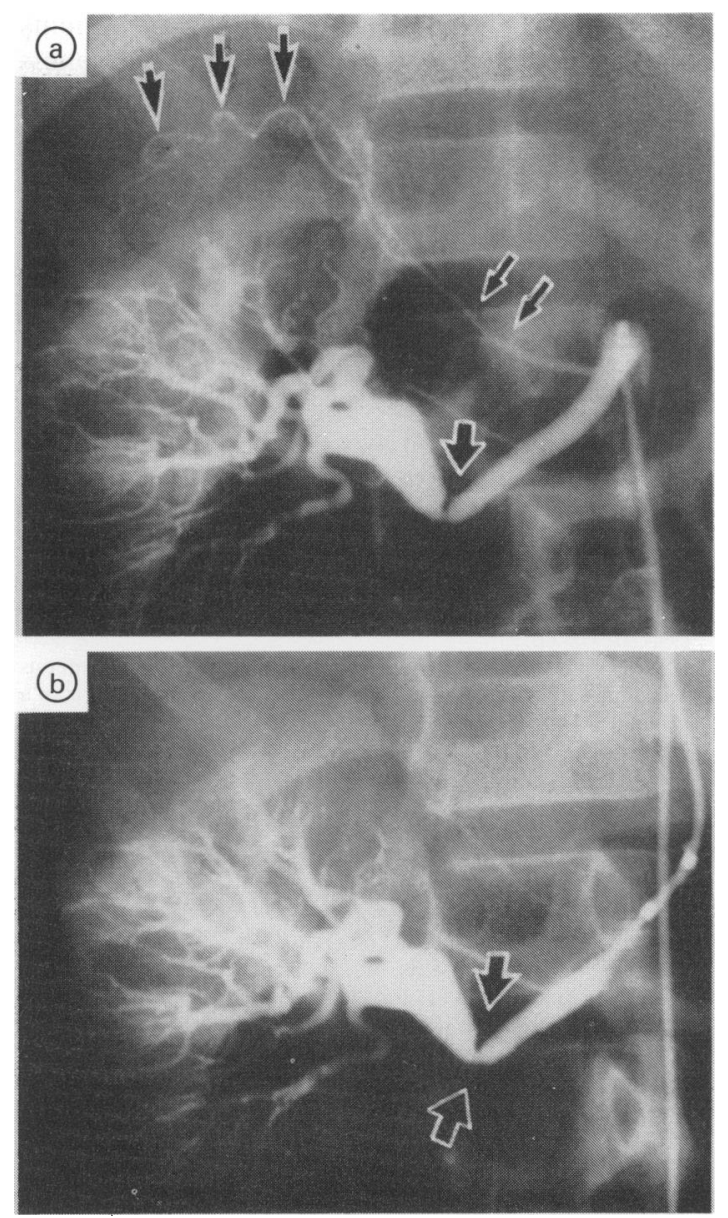

Fig. 2 Renal angiography of patient 3 with right renal artery stenosis before (a), and immediately after (b) the first angioplasty. Note that the extrarenal circulation (indicated by three arrows) was no longer identified after angioplasty. Residual stenosis was observed. years later, and again no restenosis was observed. Patient 3 developed stenosis again seven months later and angioplasty was repeated. A third angiography 10 months later still showed stenosis. In patient 5 , the catheter could not be introduced to the narrowest part of the long stenotic segment, and angioplasty was thus applied to the proximal portion only. One year later, angiography showed that the stenosis was unchanged.

Blood pressure. The patients' blood presure fell from mean (SEM) $164(33) / 135(15) \mathrm{mm} \mathrm{Hg}$ to $127(8) / 81(9) \mathrm{mm} \mathrm{Hg}$ after one month. In only one patient did blood pressure rise again, and angioplasty was repeated. The other four patients' blood pressure remained improved throughout the observation period.

Medication. Patients 2, 4, and 5 required no medication. In patient 1 and 3, different hypotensive agents were used before and after angioplasty. Although these failed to control blood pressure before angioplasty, normal values have subsequently been maintained with medication.

Endocrinological study. (Table 2). In patients 1, 2, and 3 (after the first angioplasty), plasma renin activity in the inferior vena cava and renal veins decreased. The renin ratio (stenotic/contralateral) decreased in patient 1 , and remained unchanged in patients 2 and 3 (after the first angioplasty). In patient 3 both the plasma renin activity and renin ratio increased after the second angioplasty.

\section{Discussion}

Five patients with renovascular hypertension were treated with angioplasty. Throughout the follow up period ranging from 12 to 32 months, four patients showed normal and one patient showed improved

Table 2 Plasma renin activity (PRA) in patients with renovascular hypertension, from inferior vena cava and both renal veins before $(n=5)$ and after $(n=3)$ percutaneous transluminal angioplasty (PTA)

\begin{tabular}{|c|c|c|c|c|}
\hline \multirow[t]{2}{*}{ Patient No } & \multicolumn{3}{|c|}{ PRA (ng/ml per hour) } & \multirow{2}{*}{$\begin{array}{l}\text { Renin ratio } \\
\text { (stenotic/contralateral) }\end{array}$} \\
\hline & Vena cava inferior & $\begin{array}{l}\text { Renal vein } \\
\text { (stenotic side) }\end{array}$ & $\begin{array}{l}\text { Renal vein } \\
\text { (contralateral) }\end{array}$ & \\
\hline $\begin{array}{l}\text { (1) Before } \\
\text { After } 12 \mathrm{mths}\end{array}$ & $\begin{array}{l}56 \cdot 0 \\
14 \cdot 2\end{array}$ & $\begin{aligned} &> 85 \\
& 24 \cdot 9\end{aligned}$ & $\begin{array}{l}28 \cdot 9 \\
16 \cdot 1\end{array}$ & $\begin{array}{r}<2.9 \\
1.5\end{array}$ \\
\hline $\begin{array}{l}\text { (2) Before } \\
\text { After } 12 \mathrm{mths}\end{array}$ & $\begin{array}{r}24 \cdot 1 \\
9 \cdot 4\end{array}$ & $\begin{array}{l}25 \cdot 3 \\
11 \cdot 7\end{array}$ & $\begin{array}{l}22 \cdot 7 \\
10 \cdot 9\end{array}$ & $\begin{array}{l}1 \cdot 1 \\
1 \cdot 1\end{array}$ \\
\hline $\begin{array}{l}\text { (3) Before } \\
\text { After } 7 \mathrm{mths} \text { (before 2nd PTA) } \\
\text { After } 17 \mathrm{mths}\end{array}$ & $\begin{array}{r}21 \cdot 9 \\
1 \cdot 0 \\
7 \cdot 9\end{array}$ & $\begin{array}{l}28 \cdot 2 \\
10 \cdot 3 \\
47 \cdot 1\end{array}$ & $\begin{array}{r}19 \cdot 0 \\
2 \cdot 1 \\
19 \cdot 5\end{array}$ & $\begin{array}{l}1 \cdot 5 \\
1 \cdot 5 \\
2 \cdot 4\end{array}$ \\
\hline (4) Before & 25.9 & $52 \cdot 6$ & $17 \cdot 1$ & $3 \cdot 1$ \\
\hline (5) Before & $17 \cdot 4$ & $20 \cdot 6$ & $22 \cdot 0$ & 0.9 \\
\hline
\end{tabular}


blood pressure values. These results are very encouraging. The effectiveness of angioplasty in our patients was confirmed by angiographic and endocrinological findings. Follow up angiography showed improvement in patients 1 and 2 and no change in patient 5 , in whom the dilatation of the narrowest segment was impossible. In patient 3 , restenosis occured after the first and second angioplasty. The third angioplasty will be performed when control with medication becomes impossible.

Plasma renin activity in the vena cava and renal veins decreased in three out of four occasions. This finding confirms the role of renin-angiotensinaldosterone axis in the pathogenesis of renovascular hypertension. A renal vein renin ratio above 1.5 is considered to be important, ${ }^{7}$ but two patients of the five showed ratios below $1 \cdot 5$. Furthermore, in two patients, the ratio did not change after angioplasty. This clearly shows the difficulty of diagnosing and predicting the prognosis of this disease. ${ }^{7}$ In three patients, 1-sarcosine, 8-isoleucine angiotensin II infusion was performed and the blood pressure decreased in all. This finding also supports the role of renin-angiotensin-aldosterone system. Interpretation of the results, however, should be done with care because this test sometimes gives false negative results. ${ }^{8}$ Therefore, patient selection for angioplasty should be dependent on angiography.

Renal function in these patients was within the normal range both before and throughout the follow up period and no complications were observed. Care should be taken, however, to avoid possible complications such as thrombosis.

There has been little experience with angioplasty in children. Our experience with five patients followed for 12 to 32 months shows the effectiveness of the procedure. Angioplasty may prove to be of great use in the treatment of children because it is non-invasive and may be undertaken on repeated occasions.

\section{References}

${ }^{1}$ Grüntzig A, Vetter W, Meier B, Kuhlmann V, Lütolf U, Siegenthaler W. Treatment of renovascular hypertension with percutaneous transluminal dilatation of a renal-artery stenosis. Lancet 1978; $\mathbf{i}: 801-2$.

2 Kuhlmann U, Vetter W, Furrer J, Lütolf U, Siegenthaler W. Treatment by percutaneous transluminal dilatation. Ann Intern Med 1980;92:1.

${ }^{3}$ Madias N, Kwon OJ, Millan VG. Percutaneous transluminal renal angiography. Arch Intern Med 1982;142:693-7.

${ }^{4}$ McCook TA, Mills SR, Kirks DR, et al. Percutaneous transluminal renal artery angioplasty in a $31 / 2$-year-old girl. $J$ Pediatr 1980;97:958-60.

5 Barth KH, Brusilow SW, Kanfman SL, Ferry FT. Percutaneous transluminal angioplasty of homograft renal artery stenosis in a 10-year-old girl. Pediatrics 1981;67:675-7.

${ }^{6}$ Goertz KK, Linshaw MA, Lee KR, Hermreck A, Mattioli L, Bailie MD. Transluminal arterial dilation of a postsurgical stenosis of renal artery implant in a child with recurrent hypertension. Pediatrics 1982;69:489-91.

7 Strong CG, Hunt JC, Sheps SG, Ross MT, Bernatz P. Renal venous renin activity: enhancement of sensitivity of lateralization by sodium depletion. Am J Cardiol 1971;27:602-11.

${ }^{8}$ Case DB, Wallace JM, Keim HJ, Sealey JE, Laragh JH. Usefulness and limitations of saralasin, a weak competitive agonist of angiotensin II, for evaluating the renin and sodium factors in hypertensive patients. Am J Med 1980;60:825-36.

Correspondence to Dr M Awazu, Department of Physiology and Biophysics, Mayo Clinic, Rochester, Minnesota 55905, USA.

Received 4 April 1985 